persons doing repetition work by the aid of special appliances, the products of mechanical engineering. In the course of his address, Mr. Taylor referred at length to the functions and designing of lenses, the properties and the production of optical glass and the various workshop processes by which lenses are cut, ground, polished and tested. It was in connexion with work on photographic lenses that the need was felt for screw-threads much more accurate in form, more free from pitch and periodic error, and this in turn led to improved technique of screw-thread measurement, gauging and generation.

\section{Andrew Laing Memorial Lecture}

The winter session of the North-East Coast Institution of Fngineers and Shipbuilders was opened on October 21 by the delivery at Newcastle. upon-Tyne of the presidential address by Mr. R. J. Walker, who since 1899 has been associated with the Pursons Steam Turbine Co., Ltd., of which after the death of Sir Charles Parsons he became chairman and managing director. At the following meeting of the Institution, held on October 28, Engr. Vice-Admiral Sir R. W. Skelton, the Engineer-in-Chief of the Fleet, delivered the first Andrew Laing lecture. Laing, who was born in Edinburgh on January 31, 1856, and died in Newcastle on January 24, 1931, from 1877 until 1896 was connected with the Fairfield Shipbuilding and Fngineering Co., Govan, and from 1896 until the time of his death was managing director of the Wallsend Slipway and Engineering Co. His life's work was mainly connected with the design and construction of the machinery of Atlantic liners, his most famous ship being the Mauretania, built in 1907, which for twenty-three years held the 'blue ribbon' of the Atlantic. The construction of this vessel and her ill-fated sister ship the Lusitania was due to circumstances somewhat akin to those existing to-day, when the fastest vessels in the mercantile marine are not rogistered as British vessels. The initial step was the formation of an Adrniralty committee in 1902 which was directed to inquire into the principles on which subsidies were being given and to consider how and at what cost vessels could be secured which should combine great speed with a large radius of action. The outcome was an agreoment between the Government and the Cunard Co. whereby the Government agreed to advance a sum of money at 23 per cent interest for the construction of two ships and to increase the unnual subsidy. The bold step of adopting steam turbines for the vessels was due to the report of a technical committee on which Iaing served.

\section{Memorial to Sir Gregory Foster, Bt.}

A FUnd has been raised for tho establishment of a memorial to the late Sir Gregory Foster, at College Hall, London, a hall of residence for women students in the University with which ho was connected for more than thirty years, during twenty-one of which he was chairman of the Council. The memorial has taken the form of the provision of teak doors throughout the public rooms of the new buikling for the Hall recently erected in Malet Street and to be opened by H.M. the Queen on November 10. A memorial tablet designed by Mr. Brook Kitchin has also been placed in the entrance hall and bears a record of the services rendered by Sir Gregory Foster. A portrait painted by Mrs. Macleod has now been finished and has been hung in the council room of the Hall. It represents the sitter not as his friends knew him in the last years of his life, but as he will be remembered by those who knew him in the fullness of his strength and vigour, thus providing an interesting comparison with the portrait recently painted by Sir William Orpen which hangs in University College. The memorial tablet was unveiled on November 4 by Sir Alexander Gibb, who succeeded Sir Gregory Foster as chairman of the Council of College Hall. Ahout a hundred or so of those who had subscribed to the memorial fund were present, and for the greater number of these the occasion presented the first opportunity of seeing the new building, which in itself is the greatest and most lasting memorial to Sir Gregory Foster's work in providing increased residential accommodation for the students of the University of London.

\section{Huxley Memorial Medal and Lecture}

The presentation of the Huxley Memorial Medal of the Royal Anthropological Institute for 1932 to Prof. C. (x. Seligman will take place on November 29, when Prof. Seligman is to deliver the Huxley Memorial Lecture at 8.30 P.M. Prof. Seligman is already a medallist of the Royal Anthropological Institute, having been awarded the Rivers Memorial Medal for 1926 in recognition of his work in the field in New Guinea, among the Veddas of Ceylon and in the Sudan. Prof. Seligman gained his first experience of field work as a member of the Cambridge University Expedition to the Torres Straits in 1898 under Dr. A. C. Haddon. He visited New Guinea again as joint leader of the Cooke-Daniels Ethnographical Expedition in 1904, publishing his results in "The Melanesians of British New Guinea" (1910). His studies of the Veddas in 1907, in which he was assisted by Mrs. Seligman, were published as "The Veddas" in 1911, while the results of his investigations among the Sudanese tribes on several occasions, on which he has again been accompanied and assisted by Mrs. Seligman, are announced for publication at an early date. The study in the University of London of the customs and races of man has made substantial advances during Prof. Seligman's occupation of the chair of ethnology at the London School of Economies, especially in the promotion and organisation of training for colonial officials.

\section{Scientific Expedition to Tibet}

In February 1933 Capt. F. Kingdon-Ward is setting out to explore what is perhaps the least-known part of Tibet-the are of mountainous country which lies between the bend of the Tsangpo-Brahmaputra and the bend of the Salween. The route to be followed is : the Assam valley, Sadiya, Lohit valley, Rima, up the Rong Thod Chu, over the Ata Gang Pass (16,000 ft.)

No. 3289, Vol. 130] 